\title{
Design of a 11/2" Ram Pump and Testing the Effect of Variation in The Launch Pipe Slope Angle Against the Pump Performance
}

\author{
Rafael Mado, Alexius L. Johanis, Irene Budayawati \\ \{rafaelmadoeka@gmail.com, alexjohanis160805@gmail.com, irenebudayawati26@gmail.com\} \\ Politeknik Negeri Kupang, Indonesia
}

\begin{abstract}
Areas with higher land surface than water sources will have difficulty in obtaining a continuous water supply. One effort to meet water needs, especially in locations that are higher in position than springs, is to use a water pump. The types of pumps commonly used today are water pumps powered by electric motors or combustion engines with fuel oil (diesel or gasoline). For urban areas the need for fuel oil is not too much of a problem. Meanwhile, in rural or remote areas the existence of Fuel oil is very stepped, even if there is a very expensive price. Ram pumps can be one solution, the problem is that rivers or water sources that have high waterfalls cannot be found near the settlement area, it can only be found in remote areas far from settlements. For this reason, the purpose of this research is to design and build a ram pump with the ideal slope angle of the Launch pipe which can improve the performance of the ram pump. Conducted research using a 11/2-inch hydram pump at a $1.2 \mathrm{~m}$ fall height by varying the slope angle of the launch pipe and the Launch pipe diameter, obtained the best pump performance at $11.5^{\circ}$ angle variations and $50 \mathrm{~mm}$ pipe diameter
\end{abstract}

Keywords: ram pump, launch pipe, performance.

\section{Introduction}

One effort to meet water needs, especially in locations that are higher in position than springs, is to use a water pump. The types of pumps commonly used today are water pumps powered by electric motors or combustion engines with fuel oil (diesel or gasoline). For urban areas, the need for fuel is not too much of a problem. meanwhile, in rural or remote areas where fuel is very scarce, even if there is any it will cost a very expensive price.

The installation of a ram pump can be one solution, the problem is the minimum waterfall, according to L. Widarto dan FX. Sudarto [1] will need at least $1 \mathrm{~m}$ high with a minimum water discharge of 7 liters/minute, the higher waterfall and the greater water discharge result better of ram pump performance. Research by Muhaimin [2] et al also shows that the height factor of the incoming water source is very influential on pumping discharge, waste discharge, and the efficiency of the ram pump. To get a waterfall of more than $2 \mathrm{~m}$ high is rather difficult, even if it is possible the location would far from settlements. As for the height of $1 \mathrm{~m}$ to $1.5 \mathrm{~m}$, it can be found in areas close to settlements such as the Oeloli river at Tarus, so that a ram pump can be installed. According to the results of the research Gatut Prijo Utomo, et al. [3] show that the height of the waterfall is very influential on the ram pump head.According to Daniel Ortega Panjaitan and Tekad Sitepu [4], their study showed that the length of the Launch pipe at the ram pump affects the pumping capacity and performance of the ram pump. Research 
results from Agus Prastyo [5], shows that the larger air cylinder used, the better efficiency value will be obtained and be able to produce more water capacity.

For this reason, there is a thought to analyze the effect of the slope angle of the Launch pipe on the performance of a 11/2-inch hydram pump with the title: " Design of a 11/2 " Ram Pump and Testing the Effect of Variation in The Launch Pipe Slope Angle Against the Pump Performance". Based on the description above, the main problems in this study are: How to design and build a ram pump with an ideal slope angle to improve the ram pump performance? The objective to be achieved in this research is to design and create a hydram pump with an ideal slope angle which can improve the performance of a hydram pump.

The results of this study are expected to solve the problems mentioned above, so that the community can utilize the natural resources (river water) that are around them, for daily living needs such as drinking water, watering plants and giving livestock to drink, so the community's standard of living becomes better.

\section{Theoretical Review}

\subsection{Definition of Ram Pump}

The hydraulic ram pump is an abbreviation of ram hydraulic which comes from the words hydro = water (liquid), ram = impact, blow or pressure, so that the free translation becomes water pressure. So a hydraulic ram pump is a pump whose energy or driving force comes from the pressure or impact of water entering the pump through a pipe. The entry of water from various water sources into the pump must run continuously. Because this pump works without the need for fuel or without a motor, it is also called "Motorless Water Pump" and abbreviated as MWP. Ram pump has the ability to move water from water sources, rivers, lakes, or ponds to a place higher than the original water source.

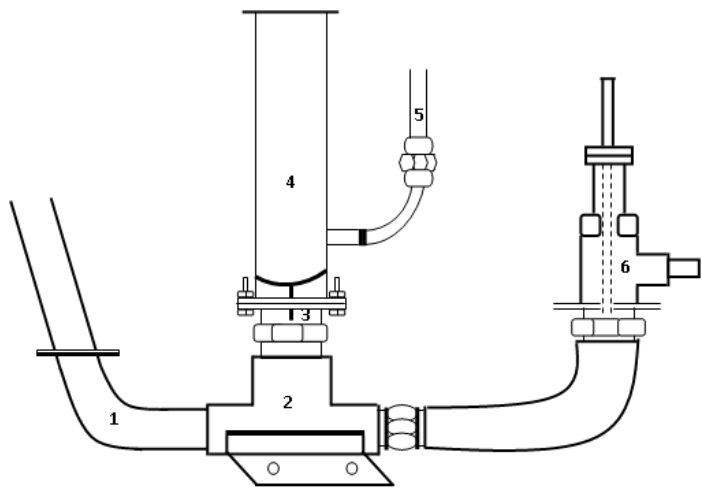

Figure 1. Ram Pump Illustration

Keterangan Figure: 1. Launch Pipe

2. Pump Housing

3. Delivery valve
4. Air Chamber

5. Delivery pipe

6. Waste Valve

\subsection{Ram Pumps Usage and Requirements}

There are so many usages from the work of this hydram pump, as follows :To irrigate rice fields and fields or plantation areas that need a continuous water supply, As a source of drinking 
water or household needs, irrigate the pond in the fishery, provide water for animal husbandry, Water supply for the needs of industry or processing factories. The resulting water is able to drive a rotating turbine because of the strength of the water that comes out of the ram pump so that it can produce electricity when connected to a generator.

In order to work well with maximum results, according to L. Widarto dan FX. Sudarto, ram pumps require some specific requirements including the following :

a. The presence of water as a potential energy source is at least 1 meter high.

b. Discharge of water needed to move the pump at least 7 liters / minute. The amount of pumping discharge can be calculated by the formula; [5]

$$
\mathrm{Q} 2=\mathrm{Q} 1 \times \mathrm{H} 1 / \mathrm{H} 2 \times \mathrm{j}
$$

Q2 = pumped water discharge (liter/minute) ; Q1 = water flow entering the pump (liter/minute),H1 = Launch Head (m) ; H2 = delivery head $(\mathrm{m}), \mathrm{j} \quad$ = pump efficiency $(0,5-$ $0,75)$

c. The size of the pump diameter is adjusted to the flow of water that enters the pump, as shown in table bellow;

Table 1. Pump size and Launch water flow

\begin{tabular}{lcccccc}
\hline Pump Diameter (inch) & 1,25 & 1,50 & 2,00 & 2,50 & 3,00 & 4,00 \\
\hline Water Flow (litre/minute) & $1-16$ & $12-25$ & $27-55$ & $45-96$ & $68-137$ & $136-170$ \\
\hline
\end{tabular}

\subsection{Ram Pump Cycles}

The ram pump work cycle can be divided into four main periods based on the position of the waste valve at the average time when there is a variation in the velocity of the water flow in the Launch pipe (Figure 2)

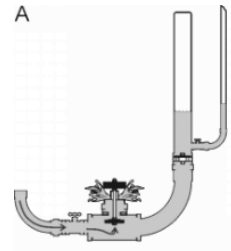

C

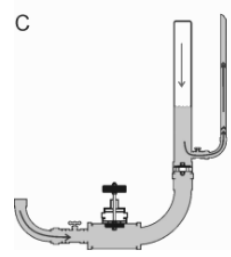

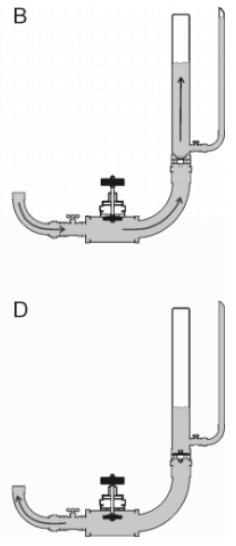

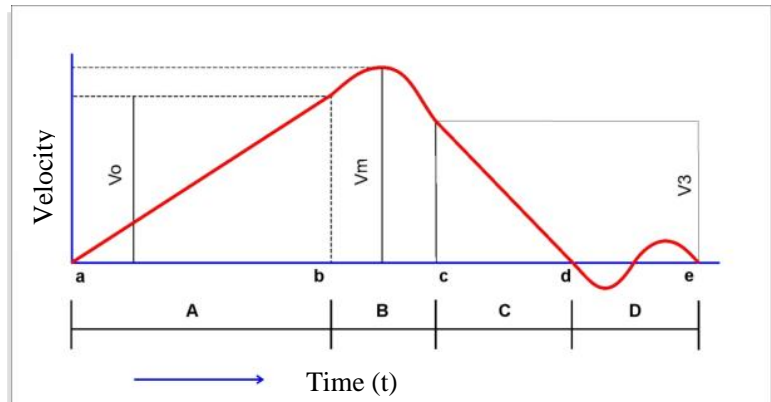

Figure 2. Ram pump work cycle 


\subsection{Water Hammer}

The water hammer process is a classic phenomenon of steady flow in pipes. To analyze the effect of water hammer complex analysis is needed. Physical events from the water hammer can be seen from two things, which is [7]: The process of storing fluids in hydraulics (generally water), which is controlled by the law of conservation of mass, while the process of changing the velocity of fluid/water caused by changes in inertia, this process is controlled by the law of conservation of momentum. If the fluid flow in a pipe is stopped suddenly, a pressure surge occurs, which can theoretically be calculated by the following equation [6] ;

$$
\Delta H=V \frac{a}{g}
$$

In Which ; $\Delta \mathrm{H}=$ Pressure rise $(\mathrm{m}), \mathrm{V}=$ Water Velocity trough the pipe $(\mathrm{m} / \mathrm{sec}), \mathrm{a}=$ The velocity of wave propagation in fluid $(\mathrm{m} / \mathrm{sec}), \mathrm{g}$ Acceleration of gravity $\left(9,8 \mathrm{~m} / \mathrm{sec}^{2}\right)$, For very rigid pipes, $\mathrm{a}=\sqrt{\mathrm{k} / \rho}, \mathrm{k}=$ water modulus of elasticity, $\rho=$ fluid density, where a is also called the velocity of sound in a fluid [7] for water, $a=1440 \mathrm{~m} / \mathrm{sec}$ [6]. The above equation gives a theoretical maximum pressure head surge, but in reality, the pressure surge that occurs will be lower because of losses in the network (head loss) and it is not possible to stop the flow suddenly [6]

The amount of force that results in the acceleration of flow in the Launch pipe can be derived from Newton's equation:

$$
\mathrm{F}=\mathrm{m} * \mathrm{a}, \text { or } \mathrm{F}=\rho * \mathrm{~A} * \mathrm{~L} * \frac{\mathrm{dV}}{\mathrm{dt}}[6]
$$

Which is $; \mathrm{F}=$ Force $(\mathrm{N}), \mathrm{a}=$ Acceleration $\left(\mathrm{m} / \mathrm{s}^{2}\right), \mathrm{m}=$ Mass $(\mathrm{kg}), \mathrm{A}=$ Crosssectional area of Launch pipe $\left(\mathrm{m}^{2}\right), \mathrm{L}=$ Length of Launch Pipe $(\mathrm{m})$, The Pressure value at point (3) obtained by dividing the force $(\mathrm{F})$ with a pipe cross-sectional area (A)[6].

One thing that must be considered when analyzing fluid flow in a pipe is potential energy loss (Head loss). In general, the energy losses above can be grouped into two, namely: major energy loss or Major head loss due to friction with the pipe wall.Minor energy loss due to connections, turns, valves, and other accessories.Head Loss due to friction with the pipe wall in a steady flow can be calculated with the Darcy-Weisbach equation [7], as follow:

$$
h_{f}=f \frac{L}{D} \frac{V^{2}}{2 g}
$$

In Which; $\mathrm{h}_{\mathrm{f}}$ : head loss due friction $(\mathrm{m}), f=$ Darcy Weisbach (friction factor), $\mathrm{L}=$ pipe Length $(\mathrm{m}), \mathrm{D}=$ pipe diameter $(\mathrm{m}), \mathrm{V}=$ water velocity $(\mathrm{m} / \mathrm{sec}), \mathrm{G}=$ acceleration of gravity $\left(\mathrm{m} / \mathrm{sec}^{2}\right)$, friction factor $(f)$ highly dependent on the flow conditions in the pipe.

\section{Research Methods}

The method used is an experimental method with independent variables namely: height of waterfall $(1.2 \mathrm{~m})$, slope angle of the Launch pipe $\left(90^{\circ}, 60^{\circ}, 30^{\circ}, 15^{\circ}\right)$, Launch pipe diameter $\left(1 \frac{1}{2}\right.$, $2^{\prime \prime}, 2^{1 / 2}$, ,) with pipe length such in Figure while the dependent variable is the lift height achieved and the water capacity produced. 
Before testing and data collection, a waterfall height of at least $1 \mathrm{~m}$ were measured and measurements of water discharge by referring to Table 1, where the pump size is $1 \frac{1}{2}$, the water discharge was 12-25 liters/minute. The test was carried out 4 times in accordance with the variation of the slope of the Launch pipe with 3 variations in the diameter of the Launch pipe. Every test is recorded carefully, especially the height of lift and the capacity of the water produced.

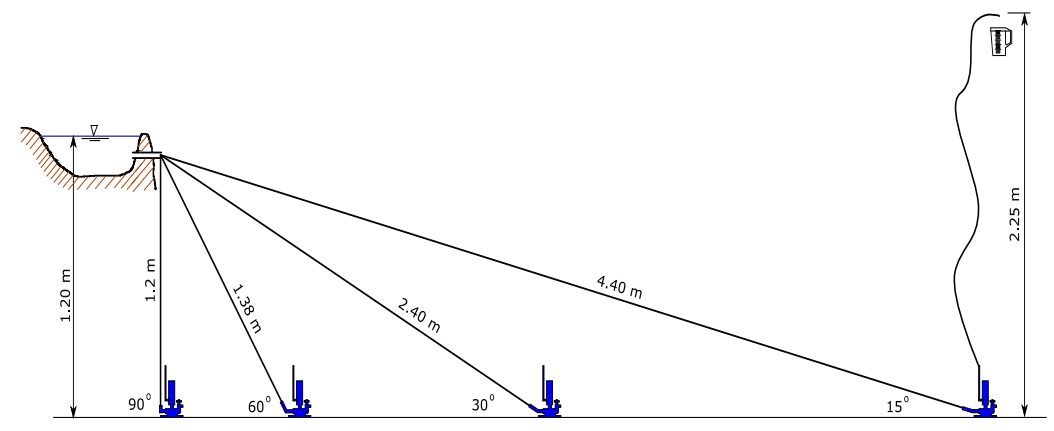

Figure 3. Research design, pump installation

\section{Results and Discussion}

Ram pumps are made with a pump body size of $11 / 2$ inches and installed at the study site as shown in Figure 4, For the Launch pipe, a PVC pipe with a thickness of $2 \mathrm{~mm}$ is used, while the discharge pipe is replaced with a $1 / 4$ inch hose with length of 24.9 meters, while the results of tests conducted as in Table 2

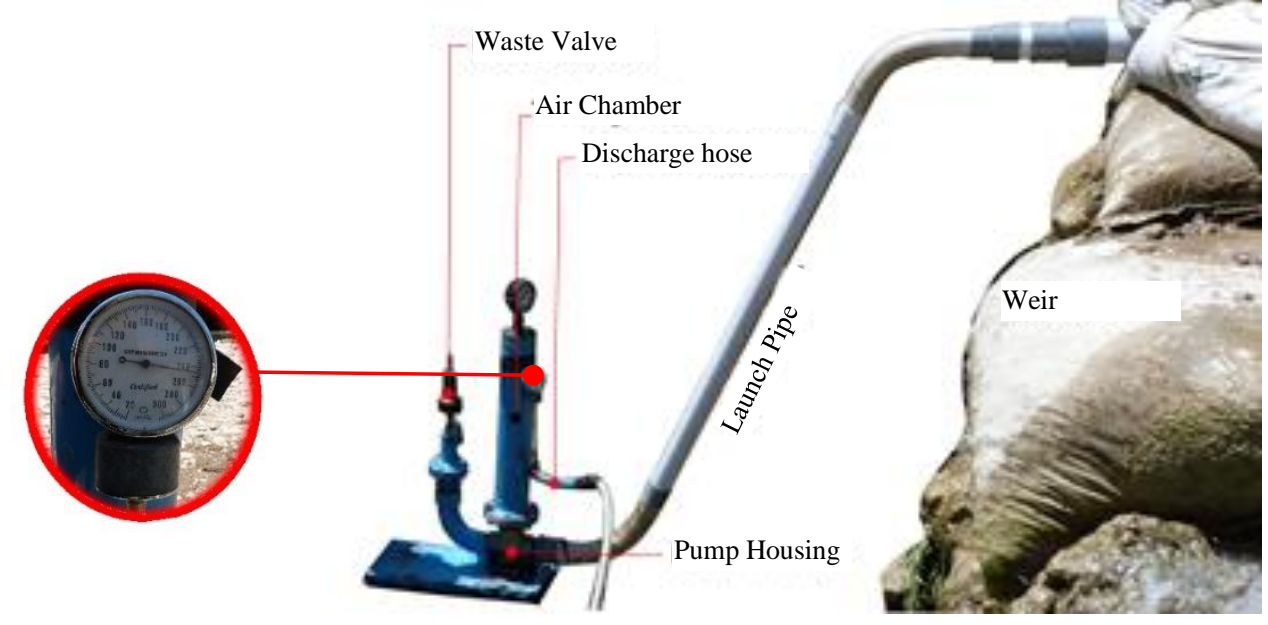

Figure 4. 11/2 inch ram pump installation 
Table 2. Test result

\begin{tabular}{|c|c|c|c|c|c|c|c|c|}
\hline \multirow[t]{2}{*}{ No } & \multicolumn{3}{|c|}{ Launch pipa } & \multirow{2}{*}{$\begin{array}{c}\text { Qin } \\
\text { (liter/sec) }\end{array}$} & \multirow{2}{*}{$\begin{array}{c}\text { Qw } \\
\text { (liter/sec) }\end{array}$} & \multirow{2}{*}{$\begin{array}{c}\text { Qd } \\
\text { (liter/sec) }\end{array}$} & \multirow{2}{*}{$\begin{array}{c}\text { Discharge } \\
\text { pressure } \\
\text { (mm Hg) }\end{array}$} & \multirow{2}{*}{$\begin{array}{c}\text { Waste } \\
\text { valve } \\
\text { pulse }\end{array}$} \\
\hline & $\begin{array}{c}\text { Angle } \\
\left({ }^{\circ}\right)\end{array}$ & $\begin{array}{c}\text { Id } \\
(\mathrm{mm})\end{array}$ & $\begin{array}{l}\text { Length } \\
\text { (m) }\end{array}$ & & & & & \\
\hline 1 & 15 & 46 & 4.44 & 0.23 & 0.22 & 0.01 & 160 & 20 \\
\hline 2 & 15 & 59 & 4.44 & 0.167 & 0.16 & 0.007 & 210 & 210 \\
\hline 3 & 15 & 71 & 4.44 & 0.134 & 0.13 & 0.004 & 230 & 180 \\
\hline 4 & 30 & 46 & 2.4 & 0.132 & 0.125 & 0.007 & 225 & 168 \\
\hline 5 & 30 & 59 & 2.4 & 0.103 & 0.1 & 0.003 & 220 & 240 \\
\hline 6 & 30 & 71 & 2.4 & 0.131 & 0.13 & 0.001 & 220 & 150 \\
\hline 7 & 60 & 46 & 1.38 & 0.152 & 0.15 & 0.002 & 258 & 144 \\
\hline 8 & 60 & 59 & 1.38 & 0.13 & 0.13 & 0 & 235 & 264 \\
\hline 9 & 60 & 71 & 1.38 & 0.07 & 0.07 & 0 & 187 & 288 \\
\hline 10 & 90 & 46 & 1.2 & 0.16 & 0.16 & 0 & 230 & 186 \\
\hline 11 & 90 & 59 & 1.2 & - & - & - & - & - \\
\hline 12 & 90 & 71 & 1.2 & - & - & - & - & - \\
\hline
\end{tabular}

The inner diameter of the Launch pipe (Id) is obtained by reducing the diameter of the pipe to the thickness of the pipe, while the outer diameter of the PVC pipe in millimeters is, among others; $50 \mathrm{~mm}$ (11/2 inches), $63 \mathrm{~mm}$ ( 2 inches) and $75 \mathrm{~mm}$ ( $2 \frac{1}{1 / 2}$ inches) [9], while the flow of water entering the pump when the pump is running (Qin) $=$ wasted discharge at the waste valve $(\mathrm{Qw})+$ pumping discharge ( $\mathrm{Qd})$.

When experimenting at $60^{\circ}$ angle variations using $75 \mathrm{~mm}$ and $63 \mathrm{~mm}$ Launch pipe diameters, the pump is no longer able to produce pumping discharge, as well as 90 degree angle variations, for the use of all three pipe diameter variations, so measurements can only be made for 2-inch Launch pipe diameters, in addition to the data an experiment was conducted with an angle of 11.5 degrees using a $75 \mathrm{~mm}$ pipe along a $6.3 \mathrm{~m}$ pipe with the following test results ;

Table 3. Test results with an angle variation of $11.5^{\circ}$ with a $50 \mathrm{~mm}$ Launch pipe diameter

\begin{tabular}{|c|c|c|c|c|c|c|c|c|}
\hline \multirow{2}{*}{ No } & \multicolumn{3}{|c|}{ Launch Pipe } & \multirow{2}{*}{$\begin{array}{c}\text { Qin } \\
\text { (liter/sec) }\end{array}$} & \multirow{2}{*}{$\begin{array}{c}\text { Qw } \\
\text { (liter/det) }\end{array}$} & \multirow{2}{*}{$\begin{array}{c}\text { Qd } \\
\text { (liter/sec) }\end{array}$} & \multirow{2}{*}{$\begin{array}{c}\text { Discharge } \\
\text { pressure } \\
\text { (mm Hg) }\end{array}$} & \multirow{2}{*}{$\begin{array}{l}\text { Waste } \\
\text { valve } \\
\text { pulse }\end{array}$} \\
\hline & $\begin{array}{c}\text { Angle } \\
\left({ }^{\circ}\right)\end{array}$ & $\begin{array}{c}\text { Id } \\
(\mathrm{mm})\end{array}$ & $\begin{array}{c}\text { Length } \\
\text { (m) }\end{array}$ & & & & & \\
\hline 1 & 11.5 & 46 & 6.3 & 0.1083 & 0.095 & 0.0133 & 242 & 162 \\
\hline
\end{tabular}

From the graph it can be seen several trends that illustrate the effect of the slope of the Launch pipe on the ram pump performance, pumping discharge tends to decrease with increasing angle, while wasted discharge tends to increase causing pump efficiency to decrease. The greater the diameter of the Launch pipe, the pumping discharge decreases, this can be caused by the decrease in the flow velocity in the pipe for the larger pipe diameter, where the 
effect of the water hammer is very dependent on the flow velocity of the Launch pipe as in equation $\Delta H=V \frac{a}{g}$

(2), Amount of water entering the pump

is also influenced by the slope of the Launch pipe and the variation of the diameter of the Launch pipe, where the magnitude of the force to close the waste valve in equation $\mathrm{F}=\mathrm{m} * \mathrm{a}$, or $\mathrm{F}=\rho * \mathrm{~A} * \mathrm{~L} * \frac{\mathrm{dV}}{\mathrm{dt}}$

(3) is strongly influenced by the Launch pipe cross-sectional area which depends on the Launch pipe diameter marked by the number of pulsations increasing for variations the larger diameter of the Launch pipe, the large force accelerates the process of closing the sewage valve. Following are the test results that are displayed in graphical form;
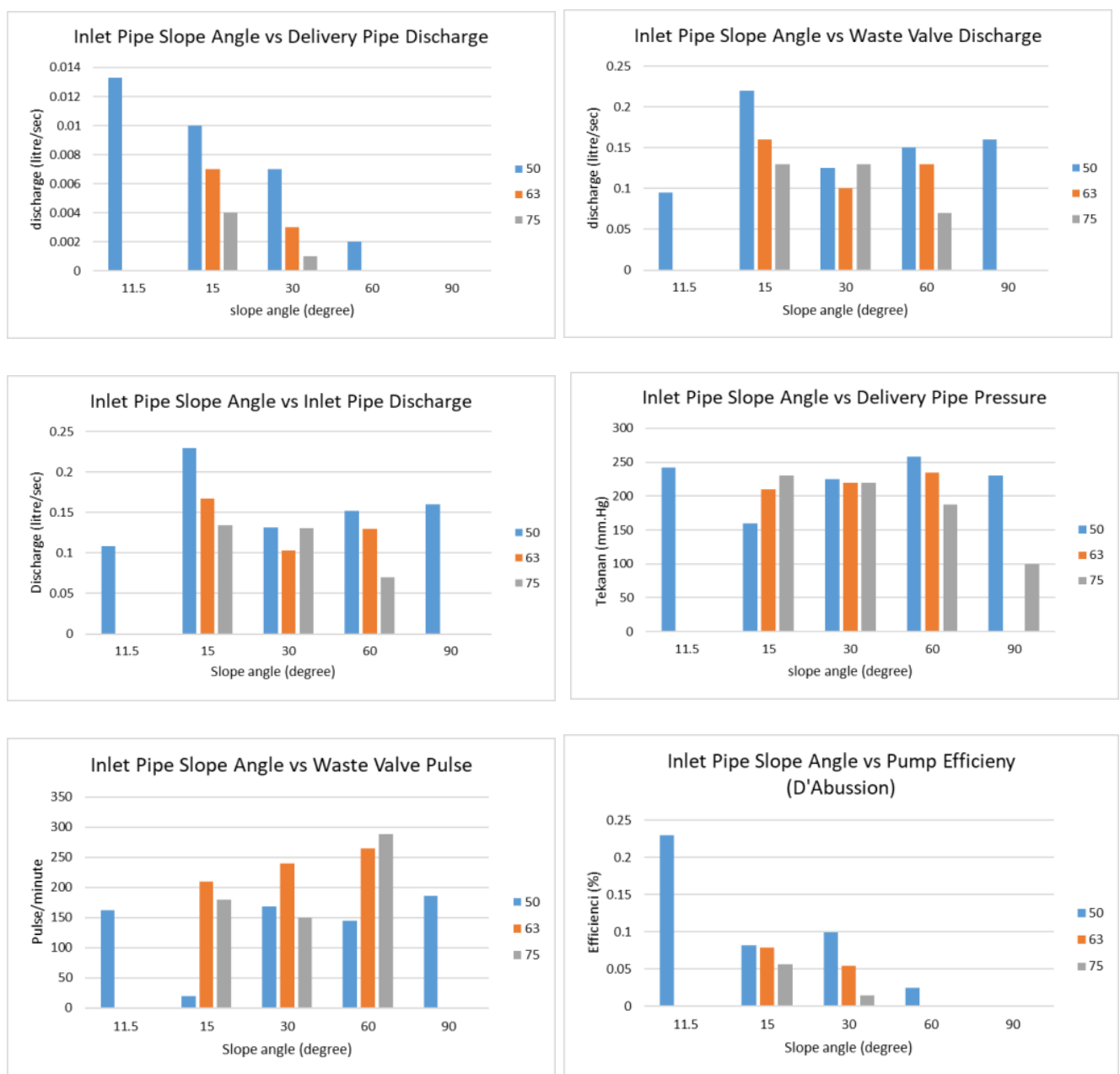

Figure 5. Experiment Result Graph 
The pressure read on the pressure gauge is more influenced by the height of the end of the discharge hose $(\mathrm{H} 2)$, the use of the hose as a delivery pipe also affects the amount of headloss that occurs in accordance with equation $h_{f}=f \frac{L}{D} \frac{V^{2}}{2 g}$

\section{Conclusions}

From the data generated and graph analysis it can be concluded several points as follows ;

a. The magnitude of the slope angle of the sliding pipe and the diameter of the launch pipe have an effect on the performance of the ram pump,

b. The greater the Launch pipe angle, the shorter the Launch pipe which affects the number of pulses per minute from the waste valve that becomes increased,

c. The diameter of the launch pipe affects the force that moves the waste valve and determines the amount of pulse.

d. The ram pump efficiency decreases with the increasing angle of the Launch pipe.

\section{Bibliography}

[1] W. d. F. Sudarto, Membuat Pompa Hidram, Jakarta: Kanisius, 1997.

[2] Muhaimin, dkk, "Pengaruh Ketinggian Sumber Air Terhadap Efisiensi Pompa Hidram," Jurnal Widya Teknik, vol. 24, no. 2, 2016.

[3] Gatut Prijo Utomo dkk, "Analisa Pengaruh Tinggi Jatuh Air Terhadap Head Pompa Hidram,” Jurnal Pengabdian LPPM Untag Surabaya, vol. 01, no. 02, pp. 211 - 224, 2015.

[4] Daniel Ortega Panjaitan, Tekad Sitepu, "Rancang Bangun Pompa Hidram dan Pengujian Pengaruh Variasi Tinggi Tabung Udara dan Panjang Pipa Pemasukan Terhadap Unjuk Kerja Pompa Hidram,” Jurnal e-Dinamis, vol. II, no. 2, 2012.

[5] A. Prastyo, "Analisa Pengaruh Dimensi Tabung Udara Terhadap Prestasi Pompa Hidram Prototype," Jurusan Teknik Mesin Fakultas Teknik Universitas Muhammadyah Jember.

[6] T. Taye, "Hydraulic Ram Pumps," Journal of the Ethiopian Society of Mechanical Engineers, vol. II, no. 1, 1998.

[7] Kodoatie, Robert J, Hidrolika Terapan, Yoyakarta: Penerbit Andi, 2002.

[8] Sularso ; Tahara, Haruo,, Pompa dan Kompressor, Jakarta: Pradnya Paramita, 1990.

[9] "Denya Corporation," PVC/ HDPE Pipe and accesiries, 2003. [Online]. Available: https://denya.co.id/wp-content/u. [Diakses 2508 2019].

[10] Dinar M. F, dkk, dalam Seminar Kontribusi Fisika, 2013 (SKF2013), Bandung, 2013.

[11] Warta Teknologi Tepat Guna, Tahun III No.32, Yogyakarta: Yayasan Dian Desa. 